\title{
ASPM wt Allele
}

National Cancer Institute

\section{Source}

National Cancer Institute. ASPM wt Allele. NCI Thesaurus. Code C118990.

Human ASPM wild-type allele is located in the vicinity of $1 \mathrm{q} 31$ and is approximately $63 \mathrm{~kb}$ in length. This allele, which encodes abnormal spindle-like microcephaly-associated protein, is involved in the regulation of the mitotic spindle. Mutation of the gene is associated with primary microcephaly type 5 . 